\title{
The Indonesian Socialist Party (PSI) 1950-1959: Political Role and Progress during Liberal Democracy
}

\author{
Armedyestu Priyonggo, Yety Rochwulaningsih, Indriyanto \\ Magister Ilmu Sejarah, Fakultas Ilmu Budaya, Universitas Diponegoro \\ *Penulis Korespondensi: aproinggo@gmail.com
}

Received:

July 2, 2018

Accepted:

October 28, 2018

\section{Abstract}

The establishment of PSI was a continuation of the movement of youth groups during the period of the National Movement which the members came from intellectual elites named PNI Baru. This organization had an important role in the form of Parliamentary Democracy system in Indonesia. During independence period, PNI Baru became a political party called Partai Rakyat Sosialis (Paras), Paras then affiliated with Partai Sosialis Indonesia (Parsi) to become the Partai Sosialis in the late of 1945. Partai Sosialis appeared convincing as the dominating party in the course of Indonesian politics in early independence, placing Sjahrir and Amir as cabinet leaders for five consecutive periods. After the name of Partai Sosialis changed into PSI on February 12, 1948, the party was unable to be considered as a potential political party anymore. PSI had no chance to contribute to the political dynamics of Indonesia at that time. It was only after the recognition of Indonesian sovereignty that the PSI was able to carry out effective party work, including their involvement in cabinet in the 1950s. The PSI members were responsible of serving the government as ministers in the structure of the Natsir Cabinet of 1950, the Wilopo Cabinet of 1952 and Burhanuddin Harahap Cabinet of 1955, the other figures who had special affiliation and sympathy with PSI also became party representatives to serve the government during that period.

Keywords: PSI; Political Dynamics; Liberal Democracy.

\section{Introduction}

The political dynamics of Indonesia in the 1950s appeared from the struggle of political parties that came into being after the implementation of the parliamentary government system in Indonesia in November 1945. The political struggle between parties in the Parliamentary Democracy system is a necessity, but for politically unstable country it might seem a worrying problem. The system often underlies the division of political parties in case of ideological flows that lead to the interests in power in each period of the cabinet or government. Almost all of political parties try to give a big influence and play an active role in determining the cabinet photofolio, so that in each journey the political dynamics seems quite fierce.

The complexity of Indonesia's political conditions and the intense rivalry between political parties at that time, was directly the trigger for the cabinet reshuffle in a relatively short period of time. Recorded during the implementation of the Parliamentary Government system in Indonesia from 1945 to 1949, it had experienced seven cabinet changes, those were (i) Sjahrir Cabinet I from Partai 
Sosisalis, (ii) Sjahrir Cabinet II from Partai Sosisalis, (iii) Sjahrir Cabinet III from Partai Sosisalis, (iv) Amir Cabinet I from Partai Sosialis, (v) Amir Cabinet II from Partai Sosialis, (vi) Hatta Cabinet I from Non-Party, and (vii) Hatta Cabinet II from NonParty (Puspoyo, 2012: 40-45).

Based on that record, it shows that in the course of the cabinet at that time it was only Partai Sosialis which dominated the structure of the cabinet. The dominance of Partai Sosialis in the five cabinet periods indicates that the party is a large and considerable party. Partai Sosialis through its representatives also succeeded in playing an important role in initiating policies that determine the ideal concept of political structure in Indonesia. One of the important roles of Partai Sosialis is to fight for democracy as political system in Indonesia.

In its development, on February 12, 1948 Partai Sosialis changed its name into Partai Sosialis Indonesia (PSI) (Tim Buku Tempo, 2010: 215), yet for several years after this, the party remained an influential political party on the national political stage. PSI briefly sat on Liberal Democracy cabinet in 1950s, among them were Natsir Cabinet of 1950, Wilopo Cabinet of 1952 and Burhanuddin Harahap Cabinet of 1955, the other figures who had special affiliation and sympathy with PSI also became party representatives to serve the government during that period (Legge, 2003: 15).

At the same time, PSI became an influential party in the parliament by placing its members totaling 17 seats out of a total of 236 seats. PSI became party that had the third most representatives compared with PNI which had 49 seats and Masyumi Party which had 36 seats (Nuzar, et.al., 2012: 109). PSI records on the national political stage in 1950s caused PSI considered as one of the major political parties. Based on the analysis of Herbert Feith, during the period of Liberal Democracy until the period of the Guided Democracy the typology of political parties in Indonesia was divided into five major genres, namely Modernist Islam represented by Masyumi Party, Democratic Socialism represented by PSI, Radical Nationalism represented by PNI, Javanese Traditionalism represented by NU, and Communist represented by PKI (Feith dan Castles, 1988).

According to the background of this study above, the researcher conducted research to perpetuate the political struggles between parties at the time of Liberal Democracy in Indonesia and drawn on the more specific context of the dynamics of PSI struggles during the period of Liberal Democracy in 1950-1959.

\section{Method}

The method used in the preparation of this journal uses the historical method, namely the process of critically testing and analyzing footage and relics of the past (Gottschalk, 1975: 32). This is an implementation of a series of historical writing methodologies, namely heuristics, criticism, interpretation, and historiography.

Supporting documents and sources for the writing of history, especially in relation to the existence of political parties in the 1950s, came from several places, among others were first, the National Archives of the Republic of Indonesia (ANRI), there were found sources of correspondence, regulations, and the laws and regulations prevailing in 1950-1959. Second, the National Library of Indonesia. There was found PSI's Articles of Basic Basis and Bylaws (AD/ART) which could be used to determine the principles and direction of party movements. Third, the sources at the Surakarta Press Museum. There were found newspapers rregarding the movements of political parties in Indonesia in 1950-1959, especially those related to the PSI. As a source of support the author also uses a variety of books that were certainly related and relevant to the theme written. 


\section{PSI Consolidation and Development Efforts}

Since the establishment to the end of Dutch rule in Indonesia, PSI tended not to show party's activity intensively. From 1948 to 1950, the Dutch Military Aggression and ongoing diplomacy agendas did not provide sufficient space for PSI to engage in partying activities, the rest of PSI's internal activities only took place in the mid-1950s by determining the party's political program discussed in the leadership conferences party (Fakih, 2012).

It appeared that the first PSI deliberation plan had been prepared well in advance. It could be seen from the implementation which did not take long from the recognition of Indonesian sovereignty. PSI succeeded in conducting deliberations of party leaders held in Yogyakarta. The deliberations were held for approximately five days and were attended by core board of PSI such as Sjahrir, L.M. Sitorus, Djohan Sjahroezah, Soemartojo, and Hamdani, as well as some PSI leaders from the regional representatives (Anwar, 2011: 92).

The deliberations had succeeded in preparing the Basic Basis and Bylaws (AD / ART) of the Party. PSI was a new political party with an old background that insisted that socialism was still used as its principle. Chronologically, the view of socialism was the identical ideology used as the principle of the organization of PNI Baru since the 1931s. Despite this tendency, Sjahrir insisted that "all members of PSI want the new party to be a party that is free from the burden of the past" (Legge, 2003: 230). This difference was due to changes in the national political situation in the period before and after independence, so that the orientation and movement of the party must also be changed.

The maturity of PSI figures in determining the concept of their party movement through the deliberation became an interesting and strategic way for the party's journey ahead. Furthermore, it was not long from the implementation of the deliberation, in August 1950 they held a meeting attended by political parties based on the genre and representatives from each region in the parliament building to discuss the mission in formulating government policy, especially the issue of West Irian liberation. The composition of the mission was Andi Zainal Abidin from PSI, Abdul Hajat from the Labor Party, Kasima from the Catholic Party, Manai Shopian from Non-party, Sahettapy Sogel from Protestant representative, Soekiman of Islam representative, Moh. Tadjudin Nor from the Nationalists and Moh Yamin from Nonparty (Antara, 27 August 1950). The meeting was not related to PSI new working program and did not become the main focus of PSI figures. It could be seen from the representation of PSI which was not attended by party elites, but it clearly showed that PSI had strong legitimacy as a representative of the socialist party.

The legitimacy of PSI was reinforced by the large number of party members in parliament at the time. Known since in 1950 the number of PSI seats in the House of Representatives amounted to 17 seats from a total of 232 seats. Although at this time there was no clear measuring instrument in determining the strength of political parties and only based on the estimate of the establishment of the party, but PSI itself as a party of three national political forces. PSI only lost to PNI and Masyumi Party which each have 49 and 36 seats in the House of Represintative (Nuzar, et.al., 2012: 109). This reason gave PSI a path to get involved in every Liberal Democratic period cabinet journey in the 1950s.

\section{PSI Political Activities and Struggles in the Cabinet Natsir Cabinet}

The new Indonesian journey with parliamentary system was marked by the enactment of the Provisional Law in August 1950. For the first cabinet, President Soekarno immediately gave the cabinet formative mandate to Natsir as chairman of 
the Masyumi Party. ${ }^{1}$ The appointment of Natsir was a presidential award to him, because Natsir was considered able to unite the regions through an integral motion submitted at the House of Representative's meeting (Waluyo, 2009: 78). For about a month Natsir were communicating with other political parties, especially with PNI and PSI, which dominated the party forces outside the Masyumi Party at that time. Natsir's talks with PNI had always failed, Natsir finally took a political policy by prioritizing PSI as the party coalition cabinet.

In early October 1950, Natsir reported the composition of the cabinet to President Soekarno. Natsir put three people from Masyumi Party, M. Roem as Minister of Foreign Affairs, Sjafruddin Prawira Negara as Minister of Finance, and Wakhid Hasyim as Minister of Religious Affairs. Then two people from PSI namely, Mr. Tadiono Manu as Minister of Agriculture and Dr. Soemitro Djojohadikusumo as Minister of Trade and Industry. Two of PIR namely, Wongsonegoro as Minister of Justice, and Prof. Dr. Johanes as Minister of Public Works. One from Parkindo namely, Dr. Johanes Leimena as Minister of Health. One from Parindra R.P. Suroso as Minister of Labor. One from PSII, Harsono Tjokroaminoto as State Minister. One from Democrats, Pellaupessy as Minister of Information. His party was taken from non-parties, such as Sri Sultan Hamengku Buwuno IX as Deputy Prime Minister, Mr. Assaat as Minister of Home Affairs, Abdul Halim as Minister of Defense; Bahder Johan as Minister of Education.

Natsir's cabinet composition did not demonstrate the position of PSI as the party that dominates the cabinet structure, there were only two names of PSI cadres in the cabinet, but PSI had an important role in the process of drafting the cabinet structure. It was shown from the criticism of the PSI's political opponents by cornering the Natsir cabinet, as it was featured in the daily newspaper Merdeka dated September 7, 1950.

"Some of capable people in Mohammad Natsir's cabinet are available, such as Soemitro Djojohadikusumo, Bahder Johan, and Mr. Assaat, but their meaning was diminished by Soemitro, Assat and three others in the cabinet of Abdul Halim, Tadio Manu, and Hamengku Buwono, all in the power and influence of PSI. Therefore, Muhammad Natsir's cabinet is a PSI cabinet" (Harian Merdeka, 7 September 1950).

The assumption that Mr. Assaat, Abdul Halim, and Hamengku Buwono IX were PSI people never wrong, because the fact that their close relationship with PSI especially with Sjahrir could not be denied. In the theory of the Ruling Group, PSI did not take much part in obtaining power directly, but PSI had a big hand to select ministers in Natsir's cabinet (Duverger, 1984: 107). ${ }^{2}$

Besides, Natsir himself denied the allegations, he said he had a reason in choosing a cabinet structure based on expertise, or better known as "Zaken Cabinet". Natsir's statement was denied by the opposition group who said that the term of Zaken Cabinet felt less appropriate when it was used as an excuse to give a position to PSI people and set aside PNI and PKI in the cabinet structure. This caused PNI and PKI along with the Labor Party to place themselves as an opposition party (Kahin, 1952: 134).

${ }^{1}$ In fact, President Soekarno and Natsir had never been in the same way. It could be seen from every debates and arguments they both had in accordance of formulating the form of state in the early of independence period. President Soekarno required secular state while Natsir required Islamic state.

${ }^{2}$ In the theory of Ruling Group, political party which had great power could be seen from its party's influence in placing representatives to be assigned as ministries. The Ruling Group would not directly take the position but they did something by influencing the power. 
According to the history of the relationship between the Masyumi Party and PSI in the early days of independence, they had a long story of conflict. The specific reason Natsir used to consider PSI was the cabinet's working priority. Natsir Cabinet program put the reorganization and rationalization of the military bureaucracy, financial stability and increased economic activity as the main target (Feith, 1964: 153).

It was known that PSI wass one party that had good communication with the military (Alam, 2003: 259), ${ }^{3}$ as well as in implementing economic development programs, Natsir seeked to increase the economic income by pumping Indonesia's main export activities, advancing agriculture and industrial production enhancers. In that case Natsir was considering a competent figure to run it, Tandio Manu and Soemitro.

In fact, in the implementation of its economic policy Natsir Cabinet obtained results that were quite encouraging. National targets in Soemitro's industrial sector had made significant improvements to the overall national economic condition. The growth of industrial productivity had shown increasing results (Waluyo, 2009: 1952). In managing the trading income Soemitro implemented a policy called Kurs Beraneka (Multiple Rate), it is the exchange rate used for export, import and profit transfer which are separated. This policy made Indonesia's economic growth in early 1950 increased (van Bemmelen and Raben, 2011: 38-39). Despite these successes, the improvement of state revenues from the trade and industry sectors on the other hand created a new gap for the management of state finances. Corruption among customs officials, financial officers, and state foreign exchange officials became an unavoidable practice. News about corruption had been often reported in various newspapers and discussed in parliamentary meetings (van Bemmelen and Raben, 2011: 38-39).

This led to the opposition political party pressing Natsir Cabinet. Fortunately, PIR which initially agreed with Natsir turned the direction by pulling his ministers in the cabinet. The pressure from the opposition party caused Natsir's cabinet position could not be maintained, then Narsir returned the mandate to the president in March 1951.

\section{Soekiman Cabinet}

A few days after Natsir returned the mandate, President Soekarno appointed PNI representative, Mr. Sartono as a formature on April 26, 1951 (Harian Abadi, 27 Maret 1951). In arranging his cabinet, Mr. Sartono prefered to communicate with Masyumi Party. He was assisted by Sidik Djojosukarto from PNI and Soekiman from Masyumi Party. The results of the arrangement chose Soekiman as Prime Minister. Soekiman cabinet lasted until February 23, 1952, by showing a good relationship with PNI. In his cabinet composition, Soekiman considered the representation of Masyumi Party and PNI, while left parties including PSI were not involved in the cabinet structure at all.

Actually Soekiman was aware of the difference between PSI and other left parties, especially with PKI, yet Soekiman did not agree with Soemitro's economic policy at the time he served as Minister of Trade and Industry in Natsir Cabinet. In the economic policy, Soekiman considered Soemitro was more often having cooperation with the United States. While Soekiman himself preferred to do

${ }^{3}$ PSI had been known to be close to General Soedirman in the early period of independence. In the early year of 1948, PSI was able to build up relationship with some military such as A.H. Nasution as well as the soldiers. PSI had successfully infiltrated and proposed its modern ideas inside of military at that time. 
economic resistance with America, and oppose the policy of American embargo for strategic goods, textile and rubber (Alam, 2003: 258).

According to PSI, they said that Soekiman's statement could not be proven and only as a means to eliminate PSI representatives in the composition of his cabinet. After that, PSI seeked to weaken the cabinet by conducting opposition movements and holding other political parties. PSI looked for alliance to Masyumi Party after knowing that Natsir did not walk in the same way with Soekiman. From the internal Masyumi Party itself, Soekiman got a contradiction. It turned out that there were two groups within Masyumi Party, namely the old group whose orbit was Soekiman himself and the young group whose orbit was Natsir. PSI decided to cooperate with Masyumi Party who sided with Natsir in arranging a movement against the cabinet. As results, Masyumi Party who sided with Natsir issued a vote of no confidence and managed to overthrow Soekiman cabinet (Harian Abadi, April 28, 1951).

\section{Wilopo Cabinet}

After Soekiman's resignation, President Soekarno appointed a new cabinet formation, this time he appointed Sidik Djojokarto from PNI and Prawoto Mangku Saswito from Masyumi Party, because there was no agreement between the two in determining the cabinet formation, finally the formation mandate was returned to President Soekarno. By President Soekarno, PNI representatives were replaced by Wilopo. The results decided the cabinet leader must be given to Wilopo on April 3, 1952 (Noer, 1987: 260).

While deciding the composition of his cabinet, Wilopo preferred to arrange the cabinet based on cabinet's journey stability than greater development mission. In other words, Wilopo only considered the cabinet's journey as political security. He assumed that the failure of cabinets before was caused by effortless of the cabinets in pointing out opposition party, so that all of parties which considered to be potential were included to sit in the cabinet structure (Anitawati, 2009: 102).

PSI, PNI and Masyumi Party were coalition parties, and these three parties were the backbone of the cabinet. During Wilopo cabinet, PSI was able to place Mr. Lukman Wiradinata as Minister of Justice and Dr. Soemitro Djojohadikusumo as Minister of Economy again. Fortunately, Lukman Wiradinata and Soemitro were not seen as part of an expert in cabinet structure at that time, although the ministerial position corresponded to the background of their field. Soemitro was known as one of the professors in University of Indonesia with the background of Economics and Lukman as a legal expert. In the period of Wilopo cabinet, the two had merit only by issuing policies by reactivating the stock exchange in Jakarta under the Capital Market Emergency Act of 1952. The policy did not bring strategic impact on economic development on a national scale.

In his journey, Wilopo cabinet tended to be less pressured by opposition parties, only NU Party which was a bit harshly weakening the cabinet, so that Wilopo was able to carry out the cabinet programs smoothly. However, not long ago, great pressure on Wilopo cabinet came from PNI itself. This time, the resistance movement was led by Sidik Djojokarto, by supporting the Serikat Tani (Peasants' Union) to file a vote of no confidence in the cabinet, which affected the return of Wilopo's mandate to the President on June 3, 1953 (Alam, 2003: 258).

\section{Ali Sastroamidjojo Cabinet}

The political struggle in the last few cabinets showed that political conflict arose from several causes, both from ideological conflict and interests between political parties even conflict between groups within the party itself. President Soekarno realized it as 
a serious problem, so in the formation of a new cabinet President Soekarno took a political stance by appointing Wongsonegoro to represent PIR to rearrange new cabinet. Wongsonegoro was appointed from undominant power party at that time. It was intended as a middle ground for the new cabinet not to be filled with political struggles involving PNI, Masyumi and PSI.

In arranging the cabinet, Wongsonegoro took a courageous decision by only involving PNI and Islamic representatives from NU and PSII party without involving the PSI and Masyumi Party in it. In the formation of new cabinet, Ali Sastroamidjodjo was appointed from PNI as Prime Minister on August 1, 1953 (Alam, 2003: 312).

PSI and Masyumi Party felt as neglected parties after abandoned in the arrangement of the cabinet, therefore both of them decided to do weakening movement to the cabinet. PSI encouraged the Masyumi Party to re-engage Islamic parties into the formation as it was before the 1950s. They did agitation activity reported in newspaper Harian Abadi on September 8, 1953, Masyumi Party gave a judgement to NU party and PSII as parties that injured the Islamic struggle (Harian Abadi, September 8, 1953). Meanwhile, PSI itself, also did protest to the existence of two names of PKI representatives who sat in the cabinet, Yamin and Ali (Ricklef, 2005: 489). Then, the movement of PSI and Masyumi Party finally got supports from NU and PSII Party to make efforts weaken the cabinet. The opposition coalition was successfully able to make Ali cabinet returned its mandate to the President on July 20, 1954.

\section{Burhanuddin Harahap Cabinet}

More than a year of Ali Cabinet's resignation, a new cabinet had not yet been formed. The government felt so frustrated with the political work of the cabinet that rarely formulated strategic programs in the case of state development, instead it was filled with contradictions between party streams with problematic requirements. This was due to the existence of a balanced party power, so as to map the power between political parties, it was taken by election. Finally on August 11, 1955 a new cabinet was formed, led by Burhanudin Harahap from Masyumi Party. Burhanudin Harahap cabinet was the cabinet assigned to hold the first election in Indonesia.

In the effort to carry out his duties, Burhanuddin Harahap chose to accommodate the representation of all the parties that had potential and significant vote in the election, namely PNI, Masyumi Party, PSI, PKI, and Parkindo (Puspoyo, 2012: 69). Finally, by the representation of the whole party, the target of the election in 1955 could be conducted smoothly. The goal was proven, Burhanuddin Harrahap cabinet could perform a democracy stage one month after its appointment.

\section{Government Implementation After the General Election}

In 1955, general election was held and the result was only announced in March 1956. PSI hardly accepted the results, because as the party suffered a landslide defeat, it only earned about two percent of the national vote. In other words, PSI could only delegate 5 representatives to the House of Representative and 10 seats to the members of the Constutuante. Many arguments tried to explain the cause of the defeat, but Sjahrir himself as chairman of PSI chose to be wise in realizing that maybe PSI was not mature enough in calculating the strength of the electorate base (Anwar, 2011: 98).

The result of the vote also influenced the political map of the new cabinet after Burhanuddin Harahap returned his mandate in March 1956. In the formation of the new cabinet, President Sukarno used his prerogative to appoint four electionwinning political parties, so the formation consisted of PNI, Masyumi Party, NU and 
PKI representatives. This action was taken by President Soekarno as an attempt to create a more conducive cabinet composition, otherwise the political struggle between parties was still apparent at the time of the first cabinet preparation after the 1955 elections. It was marked by the Masyumi Party's refusal of PKI to participate in the formation (Harian Abadi, March 5, 1956). Finally, the process was carried out by PNI, Masyumi Party, and NU Party with the result of putting Ali Sastroamidjojo back as Prime Minister, known as the Ali Cabinet II.

Even though PSI with the election results of 1955 had to accept the fact that they could not do much in influencing the cabinet, PSI seemed to support the Ali Cabinet program, and did not carry out opposition or provocation movements as they did on the cabinet's journey before the election was held. It was according to the awareness of PSI members on the strength of his party, there was no precise instrument used to carry out to weaken the cabinet. In such situations, forcing the party members temporarily to withdraw any action in the national political dynamics, and possible activity to be carried out was conducting the party's internal agendas.

Whilst the political condition in Indonesia at the beginning of 1957 again pointed to the difficult dynamics, Ali Cabinet II problems arose after the relationship between PNI and Masyumi Party again showed bad communication. The crack in the relationship between the two was then used by PKI. By using his political maneuvers, PKI succeeded in shifting Masyumi Party by rallying the ballot, and it was proven by Masyumi Party taking out its five representatives in the cabinet. The ongoing struggle between the two forced Ali to return his mandate to President Sukarno (Puspoyo, 2012: 70).

The complexity of the political journey at that time forced the president to rethink in continuing the parliamentary democracy system, but president still compromised with the demands of most political parties to continue the system. Half-heartednessly and without pointing out representative to arrange the new formation, President directly appointed Djuanda from non-party as Prime Minister. Djuanda Cabinet was the last cabinet in the history of Liberal Democracy period in Indonesia. This Cabinet was referred to as a cabinet of works, which in the cabinet formation consisted of professional people, not the result of the party coalition (Puspoyo, 2012: 79). Representatives who sat in the cabinet structure at this time was based on recommendation of President Soekarno, not because of the consideration of the strength of political parties.

In Djuanda Cabinet, PSI actually lost the instrument to sit in the cabinet structure. PSI position was cornered after indications of involvement of one of the party members in PRRI rebellion in West Sumatra, it caused PSI completely lost its name among the National Political elites.

\section{Conclusion}

The establishment of PSI was a continuation of the movement of youth groups who came from the intellectual elites who joined PNI Baru organization during the National Movement. In the early days of independence of Indonesia, the organization had an important role in the birth of Parliamentary Democracy system and pointed Sjahrir as the first Prime Minister. At about the same time, this organization was transformed into a political party called the Partai Rakyat Sosialis (Paras).

The position of Paras was taken into account after getting collaboration with Partai Sosialis Indonesia (Parsi) led by Amir Sjarifuddin to fuse into Socialist Party at the end of 1945. It was proven that since its establishment until 1947 Socialist Party came to dominate in Indonesian politics by placing Sjahrir and Amir as cabinet 
leaders during five consecutive periods. It was the time when Socialist Party played an important role in advocating Indonesia's sovereignty from the Dutch side, by taking a rational path which was diplomacy. This brilliant attitude demonstrated by Socialist Party was able to inspire Hatta Cabinet to fight in the same way until the achievement of Indonesian sovereignty in 1949.

After the name of Socialist Party changed into PSI on February 12, 1948, the party was unable to emerge as a considerable political party. PSI did not have the opportunity to appear in the political dynamics of Indonesia at that time. But then after the recognition of Indonesia's sovereignty, PSI was able to carry out its effective party works, including in involving itself on the cabinet's journey. In the 1950s PSI representatives were believed to occupy positions as ministers in the structure of Natsir Cabinet, Wilopo Cabinet, as well as Burhanuddin Harahap Cabinet. In addition, it put PSI back as a considerable political party in Indonesia.

The achievement of PSI as one of the most influential parties in the Indonesian political stage of the 1950s did not last long. PSI was unable to create an effective organizational movement in increasing mass power in the 1955 elections, because it only got two percent of the vote or 5 seats in parliament among 17 seats in the early 1950s. The loss of base of representatives party in the parliament resulted in the decline of party positions on the way of the entire cabinet from 1956 to 1959.

\section{References}

Alam, Wawan Tunggul (2003). Perofan Bangsaku: Perofan Bung Soekarno vs Bung Hatta. Jakarta: Gramedia Pustaka Utama.

Anitawati, Iin Nur (2002). Mohammad Roem: Karier Politik dan Perjuangannya. Magelang: Yayasan Indonesiatera, 2002.

Antara, August 27, 1950.

Anwar, Rosihan (2011). Sutan Sjahrir: Negarawan Humanis, Demokratis Sejati yang Mendahului Zamannya. Jakarta: Kompas Media Nusantara, 2011.

Duverger, Maurice (1981). Partai-Partai Politik dan Kelompok-Kelompok Penekan, translated by Layla Hasyim. Jakarta: Bina Aksara.

Fakih, Farabi (2013). "Institutional Reforms of the Guided Democracy (1957-1965)". Lembaran Sejarah, Vol. 10 (1): 96-113.

Feith, Helbert (1964). The Decline Of Constitutional Democracy In Indonesia. Ithaca: Cornell University Press.

Feith, Herbert and Castles L. ed. (1988). Pemikiran Politik Indonesia 1945-1965. Jakarta: LP3ES.

Gottschlak, Louis (1975). Mengerti Sejarah, translated by Nugroho Notosusanto. Jakarta: UI Press.

Handbook of Buku Tempo (2010). Sjahrir: Peran Besar Bung Kecil. Jakarta: Tempo.

Harian Abadi, April 28, 1951.

Harian Abadi, March 27, 1951.

Harian Abadi, September 8, 1953.

Harian Merdeka, September 7, 1950.

Kahin, George Mc. Turnan (1952). Indonesia Politics and Nasionalism. Ithaca: Corner Univercity Press.

Legge, J. D. (2003). Kaum Intelektual dan Perjuangan Kemerdekaan: Peranan Kelompok Sjahrir. Jakarta: Pustaka Utama Grafiti.

Noer, Deliar (1987). Partai Islam dalam Pentas Nasional. Jakarta:LP3S.

Nuzar, Irwansyah, Pratama, R. A, Marzuki, Adie (2012). Djohan Sjahroenzah: Merajut Jejaring Perjuangan. Jakarta: Pikir Institute. 
Puspoyo, Wijanarko (2012). Dari Soekarno Hingga Yudhoyono. Solo: Era Adicipta Intermedia.

Tim Buku Tempo (2010). Sjahrir: Peran Besar Bung Kecil (Seri Buku TEMPO: Bapak Bangsa). Jakarta: Kepustakaan Populer Gramedia.

van Bemmelen, Sita and Raben, R. ed. (2011). Antara Daerah dan Negara: Indonesia Tahun 1950-an: Pembongkaran narasi Besar Integrasi Bangsa. Jakarta: Yayasan Obor Pustaka.

Waluyo, Waluyo (2009). Dari Pemberontak Menuju Pahlawan Nasional. Yogyakarta: Ombak, 2009. 